\title{
Suffering and practical life in the Romantics and in Manzoni
}

One of the most interesting aspects of Romanticism is its illustration of opposing solutions to problems of life, whether general or stemming from specific historical or social circumstances. We find in fact assertive or submissive persons, the latter usually motivated by religious considerations, though these are not always derived from orthodox Christianity. The renewed emphasis on suffering, as Schenk (100) points out, was a characteristically Romantic trait, though the ancient Greeks had hailed the discipline of suffering and Christian theorists had regularly elaborated on it. In marked contrast to the optimism of the Enlightenment, says Schenk, the Romantics can be said to have rediscovered the inevitability of human suffering; Michelet, for example, styled Géricault "the Correggio of suffering," because his paintings illustrated shipwrecks, mad scenes and executions. Indeed, many Romantics, especially in Continental Europe, adopted a conservative and traditionally Christian position, for the most part Catholic, in reaction to the sterile "illuminismo" of the eighteenth century (Frye 39). For Leopardi, on the other hand, the pointlessness of life should lead us to pity and assist our fellow human beings; our only release is through death, as he states in A se stesso. Michele Federico Sciacca puts the point succinctly:

La logica interna del suo pensiero lo porta alla svalutazione totale della vita, a porre come negativa l'esistenza e positiva la sua negazione: la morte, unica consolatrice di una vita senza scopo, spietata e insopportabile perché senza significanza, che non conforta e non redime. Il "pessimismo cosmico" non risparmia nulla, non la natura "matrigna," che per capriccio impone il dolore e per crudeltà alimenta le illusioni, non la virtù degli antichi, il desiderio della gloria, la ricerca del vero, non l'amore, ultimo superstite dei "leggiadri errori." (222-223)

Other Romantics yearned for the infinite or sought escape in nature. Byron, on the other hand, to escape the spiritual vacuity of life,

ha bisogno di vivere sempre in un'atmosfera di passioni tempestose. Anche l'azione egli la cerca non in vista dello scopo da raggiungere, ma per le emozioni che procura: quello che conta non è il possesso dell'oggetto, ma la vibrazione dell'anima (Puppo 47).

Some writers placed their protagonists in specific situations whose conditions overwhelmed them. Goethe's Werther commits suicide for reasons of love, since there was no other way out. The man who takes his life is no coward. In any case, man is transient and his memory lives on only in 
the thoughts of his loved ones, but they, too, will vanish and so will all memory of him. Jacopo Ortis commits suicide for patriotic and amorous reasons: only death can bring him peace, for the intensity of sorrow is stronger than any love of life or horror of death and takes precedence over them. As Puppo remarks: "la nobiltà del fine è comprovata e quasi creata dall'intensità della passione con cui esso è voluto. . . . L L'intensità passionale giustifica l'azione:" - and here he is referring especially to Jacopo Ortis - "Anche il dolore ha una funzione positiva: solo attraverso il dolore l'anima si nobilita" (47).

Clearly, one could refer to the attitudes of many other writers of the period, but let us deal briefly with suffering in the historical novels of Walter Scott in so far as a parallel can be drawn with I Promessi Sposi. In general, Scott, like the English novelists of the eighteenth century, depicts ruling families, the aristocracy or the new bourgeoisie in his nostalgic look at Scotland's past. An exception is The Heart of Midlothian which has certain resemblances with I Promessi Sposi, as Meiklejohn has pointed out. Here the humble family of the Deans are protagonists, though Jeanie's fiancé and later husband, Reuben Butler, is a clergyman. Christianity governs her attitudes and actions, and she theorizes as Lucia does not. It is interesting that, at one point, she tells Reuben that all must be over between him and her, since she is stained by her sister Effie's action, which would also affect their children - a situation that recurs between Mena and Alfio Mosca in Verga's I Malavoglia. A little later, Jeanie,

left alone and separated from all earthly counsel, ... had recourse to a friend and adviser, whose ear is open to the poorest and most afflicted of his people. She knelt, and prayed with fervent sincerity, that God would please to direct her what course to follow in her arduous and distressing situation ... (160)

At the end of her prayer, "Jeanie arose from her devotions, with her heart fortified to endure afflictions, and encouraged to face difficulties." She trusts in God to redeem her sister's captivity, but, in fact, she takes definite action by journeying to London and, with the support of the Duke of Argyle, obtains the Queen's promise to intervene with the King and obtain Effie's pardon. Previously, when detained en route at the house of the Stauntons, "The Lord support and direct me!" said Jeanie, "for it seems to be His will to try me with difficulties far beyond my ain strength" (368).

Václav Cerny expressed his surprise on noting the passive attitude to suffering and the readiness to forgive in the works of Italian writers of the Romantic period and mentioned Leopardi, Pellico, d'Azeglio and Manzoni: such an attitude was astonishing since conditions were such that Italy should have been "le pays par excellence des esprits enclins à la révolte contre la Destinée injuste" (72). We have referred to Leopardi and Foscolo; Pellico's Le mie prigioni (1832) describes his sufferings, endured with patience, but 
his Christian forgiveness of the Austrians not only showed his superiority but injured their reputation.

In discussing Manzoni, we must distinguish between his tragedies and I Promessi Sposi. The protagonist of Il Conte di Carmagnola, recalled to Venice by trickery and condemned to death by the Senate, like other figures in Romantic works is incapable of any positive action and must suffer his fate. In the fourth scene of Act 5, he remembers battles of the past and how, among them,

Era bello il morir. Ma . . . ripugnante

Vo dunque incontro al mio destin, forzato,

Siccome un reo, spargendo in sulla via

Voti impotenti e misere querele?

(5.236-239)

Yet, in the final scene, he tells Antonietta, his wife, Matilde, his daughter, and Gonzaga that death comes from Heaven which accompanies it with such comfort as men can neither give nor take away. As Diana Cristadoro Parra observes:

Ne scaturisce il concetto della morte che è quindi premio per il giusto, che non la recepisce mai dalle mani degli uomini che non potrebbero premiare mai adeguatamente alcuna virtù. Solo a Dio è tale potere e Manzoni, quale estremo premio ai suoi "eroi" ed alle sue "vittime," dona la morte, perché essi trovino in Dio ciò che invano hanno cercato nel mondo. (36)

Adelchi escapes, by his death, from the suffering and injustices of this life. He had done his duty by supporting his father, Desiderio, in battle against Carlo. It is his sister, Ermengarda, however, who is more related to ordinary human life. Luigi Russo pointed out that she is a "creatura moderna, ... delicatamente umana e terrena, cioè cristiana di quel cristianesimo tutto calato su questa terra, che è uno dei tratti della religione ottocentesca del Manzoni" (93). Parra, who quotes this passage, aptly comments: "E poi dobbiamo renderci conto che il Manzoni non ha voluto darci una sovrumana Beatrice dantesca, ma l'immagine di una vera donna" (50). Ermengarda is genuinely in love with Carlo:

Amor tremendo è il mio.

Tu nol conosci ancora; oh! tutto ancora

Non tel mostrai: tu eri mio: secura

Nel mio gaudio io tacea; né tutta mai

Questo labbro pudico osato avria

Dirti l'ebbrezza del mio cor segreto.

Yet she is powerless to act in order to reverse her situation or to forget her love. 
In the chorus that follows, in addition to lamenting Ermengarda's fate and her being born among the oppressors, the author advises her to end her suffering:

Sgombra, o gentil, dall'ansia
Mente i terrestri ardori;
Leva all'Eterno un candido
Pensicr d'offerta, e muori.

Manzoni refers to the sorrow of the slave woman in La Pentecoste. She cannot alleviate her suffering by any social action, but should turn to God:

Perché, baciando i pargoli,

La schiava ancor sospira?

E il sen che nutre $\mathrm{j}$ liberi

Invidiando mira?

Non sa che al regno i miseri

Seco il Signor solleva?

Che a tutti i figli d'Eva

Nel suo dolor pensò?

In I Promessi Sposi, Manzoni, for his protagonists, abandons the depiction of a person from high society whose suffering leads to heroic solitude in which he or she is faced not only by social problems, but also by the existential nature of life itself. Carlo Salinari expresses the point as follows:

Nei Promessi Sposi il personaggio-protagonista, l'eroe, è sparito, e, al suo posto, compare una folla di gente semplice e oppressa, succube dell'ingiustizia.

The attention of the reader is diverted from the individual to the crowd; thus

alla disperazione subentra l'azione e la speranza in un mondo più giusto che alberga nel cuore degli uomini. Adelchi può rappresentare l'intellettuale isolato che, di fronte a un mondo ingiusto, è sopraffatto dall'angoscia e magari cerca la morte; Renzo rappresenta il popolo che non può permettersi il lusso di disperarsi e di sopprimersi e nutre fiducia che le cose possano cssere cambiate. (119)

He goes on to indicate that, especially in the second part of the novel, existential elements become dominant, beginning with the episode of the Innominato. The identification of Renzo and especially of Lucia with the crowd should not be carried too far, however, since, as we shall see, they are individuals.

Manzoni's determination to respect the historical conditions and psychology of the earlier seventeenth century meant that, in choosing two humble "contadini" as his chief characters, he could bestow upon them only a very limited culture, of which religion would form a major part. He could also show them, howcver, as practical, given the concrete tasks imposed by their way of life. In I Promessi Sposi, Renzo, Lucia and Agnese must confront 
the injustices of a feudal age dominated by the aristocracy and the Church, as well as by foreign rule. Social and political action is impossible either individually or as part of popular movements such as the riots in Milan. Yet Renzo and Lucia take such action as they can, though Renzo learns that, in such a society, open social action is unproductive and dangerous. His journeying and resultant conduct illustrate the descent and ascent discussed by Northrop Frye in The Secular Scripture (95-157), though Manzoni is original in his application of the scheme to a humble character. Renzo and Lucia can consider life and its problems from a religious viewpoint, a capacity open to all persons according to Manzoni. As Ferruccio Ulivi comments:

È raro cioè il caso che un individuo sia posto liberamente di fronte a sé (e vedremo i limiti anche dell'Innominato). Ma ciò non vuol dire che l'uomo, un qualsiasi individuo, sia incapace di rifarsi ai principî universali di fondo; gli sviamenti verranno dall'ambiente, dall'educazione ricevuta. Ma la capacità di aprirsi al dettame della responsabilità morale esiste per tutti. (18-19)

No matter how oppressive the social and political conditions, anyone can turn to Christianity for a system of values and a course of action.

Renzo and Lucia are not mere literary figures faced with overwhelming suffering. Renzo is shown as a practical character. He accepts a delay of one week for the wedding, but has his suspicions confirmed by Perpetua's words and compels Don Abbondio to reveal the name of Don Rodrigo. Yet, for religious reasons, he rejects a violent retaliation against Don Rodrigo. He vainly consults Azzeccagarbugli and attemps a forced wedding after paying Tonio's debt to Don Abbondio, so that he and Gervaso can serve as witnesses. Afterwards Renzo is "il più in sé di tutti" (135). At Milan, he understands contrary to what the mob believes - that the destruction of bakeries will not produce more bread. His subsequent speech (241-243) correctly analyses the political situation. He does not believe the soothing words of the lawyer who has arrested him and, by his shouting, attracts the attention of a crowd and thus is able to escape. On returning to Milan during the plague, he escapes the crowd who think he is an "untore" by joining the "monatti" in a procession of carts carrying corpses. Finally, after threatening to kill Don Rodrigo, he assures Padre Cristoforo that he forgives him and so makes himself worthy to meet Lucia. Renzo remains a humble character, prepared to act to meet circumstances, though the structure of his story indicates a deeper significance of universal import.

Lucia is shown as a young woman who is governed by Christian morality, but who reacts positively rather than appealing abstractly to God. Her only culture is religion, yet she thinks what form her actions should take in conformity with it and when she should consult Padre Cristoforo. She also considers other circumstances related to society and to other characters. Of the numerous critics who have discussed her character, let us quote Rocco Montano: 
Lucia non è simbolo della semplicità di cuore, della naturale innocenza. Essa è una che sa, fa le cose consapevolmente, perché ha imparato, e la virtù è diventata la sua seconda natura. Essa non è l'anima ispirata o lo spirito dotato di grande dottrina, animato da grandi propositi e ambizioni.

And

il merito della rivelazione cristiana e dell'insegnamento della Chiesa, il Manzoni sa, è quello di poter portare - per ciò che riguarda la condotta dell'anima, l'elevatezza del sentire - la persona più umile alle altezze delle più istruite. (75)

Lucia's practicality is seen from the beginning. She consulted Padre Cristoforo in regard to Don Rodrigo's advances, but did not tell her mother of them in order to avoid having everyone know. She took the monk's advice to hasten the wedding. Now, when Renzo makes threats against Don Rodrigo, she suggests that they go far enough away so that Don Rodrigo should no longer hear them spoken about - they in fact leave their village at the end of the novel, though for other reasons. She opined "che bisognava veder d'aiutarsi in tutte le maniere" (50). Since Padre Cristoforo could both advise and act, there was a need to inform him of what had happened. When Fra Galdino comes to collect nuts, she gives him so many that he can return immediately to the monastery to summon Padre Cristoforo. She agrees to the forced wedding to quieten Renzo who had exaggerated his threats, but throughout the author makes it clear that she is deeply in love with Renzo. ${ }^{2}$ On hearing of Renzo's arrest, escape and possible recapture, she is "la desolata fanciulla," but news of his flight to the territory of Bergamo "fu un gran balsamo per Lucia" (312) and, in all her prayers, "c'era mescolato un ringraziamento" (313).

In the carriage with the "bravi" of the Innominato, Lucia tries to throw herself out by its door and only turns to God when there is no other remedy for her suffering. She uses her religious beliefs to influence the Innominato: "Non torna conto a uno che un giorno deve morire di far patir tanto una povera creatura" and "Dio perdona tante cose, per un'opera di misericordia!" (357), because they express the truth of life. Without knowing of his spiritual conflict, Lucia is reanimated by seeing "una cert'aria d'esitazione nel viso e nel contegno del suo tiranno" (358); despite her desperate plight, she is still able to observe his appearance and manner. If he does not set her free, God will do so by having her die and then all will be finished for her. Lucia is the Christian for whom her religion forms part of her character and viewpoint. Though she makes a vow to the Virgin Mary to remain a virgin, Lucia cannot forget Renzo and defends him to Donna Prassede, and finally is desirous of being released from this vow by Padre Cristoforo-a vow that had disturbed her religious position somewhat. Lucia's situation before the Virgin Mary can be contrasted with that of Ginevra in Massimo d'Azeglio's Ettore Fieramosca: before a picture of Mary, Ginevra, 
“Vergine santa e gloriosa!" diceva alfine con piena d'affetti: "chi son io per meritare la tua pietà? Eppure chi m'aiuterà se tu non m'aiuti? Ecco a' tuoi piedi i miei affanni; vedi ch'io non reggo a questa prova, e non valgo ad uscirne; oh Vergine mia pietosa, mettimi in cuore tanta forza ch'io possa ciò che pur vorrei!" (128)

In the novel of Cesare Cantù, Margherita Pusterla, Rosalia, wife of Ramengo, who accuses her of treachery, cries out in the boat:

O Signore, o Madonna Santa! - Ma voi Maria, foste anche voi madre, anche voi portaste un bambino, e fu cercato a morte, e vi toccò di camparlo fuggendo. Deh! traetevi a compassione di me: guardatemi dal cielo: datemi coraggio, datemi forza di passar questa notte, questa notte d'inferno. (144)

Lucia, then, undergoes extreme suffering, wholly possible in the feudal injustice of her age, but remains a practical character and does not become a merely literary character, a prey to despair. ${ }^{3}$

In I Promessi Sposi Manzoni relates suffering to the lives of humble people in an unjust society and shows their reaction to it. This reaction stems from their social position and, when it cannot achieve results, they turn to religion. They remain, however, practical persons who constantly seek remedies and who eventually return to ordinary life. In view of their limited culture, they do not speculate on the possibilities of religion or divine attitudes. In the depiction of such characters lies Manzoni's originality.

\section{University of Toronto}

\section{NOTES}

1 The crowd is not one homogeneous mass for Manzoni. He divides the rioters at Milan into extremists who seek to carry things to excess and "i partigiani della pace" (230), and quotes the opinions of individuals regarding the reasons for the shortage of bread and for views of Ferrer.

2 Manzoni does not refer to any physical contact between Renzo and Lucia and he avoids erotic details; he explains his attitude in Fermo e Lucia. See also Giorgio Bárberi Squarotti (20-28), who analyses Manzoni's viewpoint.

3 Lucia's words to Agnese at the house of the tailor after her return from the castle of the Innominato indicate the depth of her suffering and her trust in God: “'No, no, mamma; no!' interruppe Lucia: 'non gli augurate di patire, non l'augurate a nessuno! Se sapeste cosa sia patire! Se aveste provato! No, no! preghiamo piuttosto Dio e la Madonna per lui: che Dio gli tocchi il cuore, come ha fatto a quest'altro povero signore, ch'era peggio di lui; e ora è un santo"' (417).

\section{WORKS CITED}

Bárberi Squarotti, Giorgio. Manzoni: le delusioni della letteratura. Rovito: Marra, 1988.

Cantù, Cesare. Margherita Pusterla. Milano: Rizzoli, 1965.

Cerny, Václav. Essai sur le Titanisme dans la poésie romantique occidentale entre 1815 et 1850.

Prague: Aux Editions Orbis, 1935.

D’Azeglio, Massimo. Romanzi. Ed. Alberto Maria Ghisalberti. Milano: Mursia, 1966. 
Foscolo, Ugo. Ultime lettere di Jacopo Ortis. In Opere. Ed. Mario Puppo. Milano: Mursia, 1969,6 a edizione.

Frye, Northrop. "Il mito romantico." In Il Romanticismo. Atti del Sesto Congresso dell'Associazione Internazionale per gli Studi di Lingua e Letteratura Italiana. Eds. Vittore Branca e Tibor Kardos. Budapest: Akadémiai Kiadó, 1968. 35-52. The Secular Scripture. Cambridge: Harvard UP, 1982. Fifth Printing.

Goethe, Johann Wolfgang von. The Sorrows of Young Werther and Selected Writings. Trans. Catherine Hutter. New York: Signet Classics, 1962.

Leopardi, Giacomo. Tutte le opere. Ed. Francesco Flora. 1. Le poesie e le prose. Milano: Mondadori, 1945. 2a edizione.

Magnino, Bruna. Romanticismo e cristianesimo. 3. Valori e problemi. Brescia: Morcelliana, 1963.

Manzoni, Alessandro. Tutte le opere. Eds. Alberto Chiari e Fausto Ghisalberti. 1. Poesie e tragedie. Milano: Mandadori, 1957. 2, Tomo 1. I Promessi Sposi. Milano: Mondadori, 1965. 3a edizione.

Meiklejoh, Matthew F. M. "Sir Walter Scott and Alessandro Manzoni." Italian Studies 12 (1957). 91-98.

Montano, Rocco. Comprendere Manzoni. Napoli: G. B. Vico Editrice, 1973.

Parra, Diana Cristadoro. Clarità della morte nell'opera di Alessandro Manzoni. Poggibonsi: Lalla, 1984.

Puppo, Mario. Il romanticismo. Roma: Editrice Studium, 1973. 2a edizione.

Russo, Luigi. Ritratti e disegni storici. Firenze: Sansoni, 1965.

Salinari, Carlo. "Struttura ideologica dei Promessi Sposi." In Manzoni scrittore curopeo. Atti del Congresso Internazionale di Studi Manzoniani (Salerno 1974). Ed. Pietro Borraro. Salerno: Comitato Salernitano della Dante Alighieri, 1976. 111-125.

Schenk, Hans G. The Mind of the European Romantics. Oxford: Oxford UP, 1979.

Sciacca, Michele Federico. Il pensiero italiano nell'età del Risorgimento. Milano: Marzorati, 1963.

Scott, Walter. The Heart of Midlothian. London: J. M. Dent, Everyman Edition, 1947 (Rpt.).

Ulivi, Ferruccio. Figure e protagonisti dei Promessi Sposi. Torino: Edizioni Rai, 1967. 